\title{
Phosphorus uptake of rice plants is affected by phosphorus forms and physicochemical properties of tropical weathered soils
}

\author{
Tomohiro Nishigaki • Yasuhiro Tsujimoto • \\ Seheno Rinasoa • Tovohery Rakotoson • \\ Andry Andriamananjara • Tantely Razafimbelo
}

Received: 15 August 2018 / Accepted: 31 October 2018/Published online: 12 November 2018

(C) The Author(s) 2018

\begin{abstract}
Aims Phosphorus (P) deficiency is a major constraint for rice production in the tropics. Field-specific $\mathrm{P}$ management is key for resource-limited farmers to increase yields with minimal inputs. We used soil $\mathrm{P}$ fractionation analysis to identify the relevant factors controlling $\mathrm{P}$ uptake and the responses to $\mathrm{P}$ fertilization of rice in flooded and highly weathered soils.

Methods Phytometric pot-based experiments and a modified Hedley fractionation analysis were repeated for soils from extensive regions and from geographically adjacent fields in Madagascar.

Results Large field-to-field variations in indigenous $\mathrm{P}$ supply from soils (total $\mathrm{P}$ uptake of rice when $\mathrm{P}$ is
\end{abstract}

Responsible Editor: Terry James Rose.

Electronic supplementary material The online version of this article (https://doi.org/10.1007/s11104-018-3869-1) contains supplementary material, which is available to authorized users.

T. Nishigaki $\cdot$ Y. Tsujimoto $(\bowtie)$

Crop, Livestock and Environment Division, Japan International Research Center for Agricultural Sciences, 1-1 Owashi, Tsukuba, Ibaraki 305-8686, Japan

e-mail: tsjmt@affrc.go.jp

T. Nishigaki

e-mail: nishigaki@affrc.go.jp

S. Rinasoa $\cdot$ T. Rakotoson · A. Andriamananjara •

T. Razafimbelo

Laboratoire des Radio-Isotopes, Université d'Antananarivo, BP

3383, Route d'Andraisoro 101, Antananarivo, Madagascar omitted) and fertilizer-P recovery efficiencies (increased $\mathrm{P}$ uptake when $\mathrm{P}$ is applied) were observed not only for soils with various geological backgrounds but also for soils from adjacent fields. Regression models indicated that the indigenous $\mathrm{P}$ supply in soils was largely controlled by readily available inorganic and organic $\mathrm{P}$ pools $\left(r^{2}=0.72\right)$, whereas fertilizer-P recovery efficiencies were controlled by the abundance of oxalateextractable aluminum and iron in soils $\left(\mathrm{r}^{2}=0.81\right)$.

Conclusions Spatial heterogeneity even within adjacent fields leads to benefits from field-specific fertilizer management based on indigenous $\mathrm{P}$ supply from soils and fertilizer-P recovery efficiencies evaluated by different soil properties.

\footnotetext{
S. Rinasoa

e-mail: seheno.rinasoa@gmail.com

T. Rakotoson

e-mail: tovohery.rakotoson@gmail.com

A. Andriamananjara

e-mail: njaraandry1@gmail.com

T. Razafimbelo

e-mail: tantely.razafimbelo@gmail.com
} 
Keywords Hedley fractionation · Nutrient omission trial · Phosphorus uptake · Rice · Sub-Saharan Africa

\begin{tabular}{|c|c|}
\hline \multicolumn{2}{|c|}{ Abbreviations } \\
\hline Alo & oxalate-extractable $\mathrm{Al}$ \\
\hline ANOVA & Analysis Of Variance \\
\hline$\Delta$ Biomass & $\begin{array}{l}\text { the difference in biomass of rice plant } \\
\text { between the }+N P \text { and }+N \text { treatments }\end{array}$ \\
\hline Feo & oxalate-extractable $\mathrm{Fe}$ \\
\hline ICP & Inductively Coupled Plasma \\
\hline $\mathrm{Pi}$ & inorganic $\mathrm{P}$ in each fraction \\
\hline Po & organic $\mathrm{P}$ in each fraction \\
\hline$P_{i+o}$ & total $\mathrm{P}$ in each fraction \\
\hline$\Delta \mathrm{P}$ uptake & $\begin{array}{l}\text { the difference in } \mathrm{P} \text { uptake of rice plant } \\
\text { between the }+N P \text { and }+N \text { treatments }\end{array}$ \\
\hline SSA & Sub-Saharan Africa \\
\hline TEB & Total Exchangeable Bases \\
\hline
\end{tabular}

\section{Introduction}

Reduced availability of phosphorus $(\mathrm{P})$ in soils results in reduced biomass and grain yield of rice grown in highly weathered soils (Dogbe et al. 2015; Fageria and Baligar 1997; Koné et al. 2011, 2013). Therefore, improvement of $P$ availability in tropical weathered soils and enhancement of $\mathrm{P}$ uptake in rice plants is crucial to meet the rising demand for rice in Sub-Saharan Africa (SSA) (Nziguheba et al. 2016; Saito et al. 2015b; van Oort et al. 2015). Tropical weathered soils are typically acidic and rich in iron (Fe) and aluminum (Al) (hydr)oxides, which result in a substantial capacity to sorb phosphate (Balemi and Negisho 2012). These features may partly explain why the increase of $\mathrm{P}$ availability due to the reduced condition is less expected in highly weathered soils, while P availability generally tends to be less-limiting for paddy rice than for upland crops in equivalent soils (Fageria et al. 2011). There is also concern regarding the non-renewable use of global rock-phosphate reserves (Van Vuuren et al. 2010), and fertilization is usually neither economical nor readily available to subsistence farmers in SSA (Nziguheba et al. 2016). Hence, under such circumstances, it is necessary for farmers to adopt strategies to improve the $\mathrm{P}$ uptake of rice plants, through 1) selecting a field with a high indigenous $\mathrm{P}$ supply capacity, and/or 2) increasing fertilizer-P recovery efficiency.

In rice fields, in which soil fertility varies spatially, site-specific soil management is expected to benefit rice production (Saito et al. 2015a; Schmitter et al. 2010; Yanai et al. 2012). This may be particularly true for the fields of smallholder farmers in SSA, where the response to applied nutrients varies over small distances and is governed mostly by the influence of past management practices (Kihara et al. 2016; Schut et al. 2018; Zingore et al. 2011). In addition, our previous studies indicated that the forms of soil $\mathrm{P}$ were important for determining $\mathrm{P}$ availability in the tropics and that soil $\mathrm{P}$ forms can be affected by land management practices as well as soil properties (Nishigaki et al. 2018; Sugihara et al. 2012). Therefore, it is necessary to evaluate the spatial variation of soil $\mathrm{P}$ forms in rice fields on a regional or community scale and to elucidate the response of $\mathrm{P}$ uptake in rice to the $\mathrm{P}$ forms in soils.

The $\mathrm{P}$ fractionation method of Hedley et al. (1982) has been widely used to characterize soil $\mathrm{P}$ forms based on their availability, with the fundamental assumption being that extractants of varying strength estimate $P$ fractions of differing availability. Nevertheless, P fractions separated by the same sequential method are not of equal availability to plants in all soils (Guo et al. 2000), and rice plants draw $\mathrm{P}$ from a continuum of chemically extracted fractions that are assumed to have different plant $P$ availability (Zhang et al. 2006). In low-input systems, in which fertilizer-P additions are very low or absent, pools of $\mathrm{P}$ that are less available seem to act as a buffering pool for labile inorganic $\mathrm{P}$, particularly in highly weathered soils (Beck and Sanchez 1994; Guo et al. 2000). In addition, previous studies argued that organic $\mathrm{P}$ may play an important role in supplying available $P$ in unfertilized soils (George et al. 2018; Guo et al. 2000; Tiessen et al. 1992). However, little is known about the significance of these different $\mathrm{P}$ pools in the supply of $\mathrm{P}$ to rice plants grown on weathered soils.

The focus for low-P soils in the tropics is on increasing fertilizer-P recovery efficiency and preventing the accumulation of recalcitrant soil P (Menezes-Blackburn et al. 2017). In the normal $\mathrm{pH}$ range of agricultural soils of the tropics, $\mathrm{P}$ is mainly bound to Fe- and Al-(hydr)oxides, with the sorption reactions including the precipitation of metal phosphates (Haynes and Mokolobate 2001). Alternatively, it is widely reported that soluble organic constituents derived from the application of organic amendments can enhance $P$ solubility and mobility, as well as compete with $\mathrm{P}$ for sorption sites 
(Chassé and Ohno 2016; Guppy et al. 2005; Yan et al. 2013). It is, therefore, necessary to take into account not only the soil $\mathrm{P}$ forms, but also other soil physicochemical properties that inhibit or enhance $\mathrm{P}$ absorption by rice plants. Thus far, few studies have shown how rice $P$ uptake is regulated by soil $\mathrm{P}$ forms and soil physicochemical properties in highly weathered soils.

Relative biomass or nutrient uptake (ratio with the omission of a target nutrient relative to its full application) has been used in previous omission trials as an index to evaluate nutrient deficiency (Kihara et al. 2016; Shehu et al. 2018). Still, there are debates about this index and whether it can clearly identify the influential factors with respect to high P-fixing capacity, the originally high Psupplying capacity, and deficiencies of other nutrients. In this study, we aimed to distinguish the indigenous soil Psupplying capacity and the fertilizer-P recovery efficiency using different parameters, i.e., total $\mathrm{P}$ uptake of rice plants in the P-omitted treatment and increased $\mathrm{P}$ uptake with $\mathrm{P}$ application, respectively. Our objective was, therefore, to evaluate $\mathrm{P}$ uptake of rice plants with special reference to soil $\mathrm{P}$ forms and soil physicochemical properties in tropical weathered soils. Of particular interest was to examine the variations in $\mathrm{P}$ forms in a range of rice-field soils and to determine the factors that have a substantial effect on $\mathrm{P}$ uptake in rice plants.

\section{Materials and methods}

Soil sampling and pot-based experiments

Two sets of pot-based experiments were conducted with lowland and upland field soils collected from a wide region of the central highland of Madagascar ( $n=35$, Exp. 1) and those collected within a relatively small area of one village ( $n=16$, Exp. 2) (Fig. 1). These two sets of experiments were to confirm the applicability of the results at the landscape level in soils that have been rather affected by geological changes and at the field-scale level in soils rather affected by individual farmers' management practices. Experimental soils were taken from 0 to $15 \mathrm{~cm}$ depth as composites of four to five cores in each field and divided into two parts for the pot-based experiments and soil analysis, respectively. Each of Exp. 1 and Exp. 2 was conducted in a greenhouse at the Laboratoire des RadioIsotopes, University of Antananarivo, in Madagascar (18 53'56.0”S, 47³3'01.2"E, $1222 \mathrm{~m}$ alt.) during September to October 2016 (Exp. 1) and December 2016 to
January 2017 (Exp. 2). The daily mean temperatures throughout the growing periods ranged from 18.2 to $25.6{ }^{\circ} \mathrm{C}$ and from 21.6 to $25.9{ }^{\circ} \mathrm{C}$ in Exp. 1 and Exp. 2, respectively (Watchdog 2475, Spectrum Technologies Ltd.).

Each of the collected soils was put into a 1-1 plastic pot (13 cm diameter, $15 \mathrm{~cm}$ height). Each pot contained $1 \mathrm{~kg}$ of air-dried and sieved (4 mm) soil. In each experiment, three sets of different fertilizer treatments were established with two replicates: 1, Cont (no fertilizer application); 2, $+N\left(0.2 \mathrm{~g} \mathrm{pot}^{-1}\right.$ and $0.3 \mathrm{~g} \mathrm{pot}^{-1}$ of $\mathrm{N}$ as $\mathrm{NH}_{4} \mathrm{NO}_{3}$ in Exp. 1 and Exp. 2, respectively); 3, $+N P$ $\left(0.2 \mathrm{~g} \mathrm{pot}^{-1}\right.$ and $0.3 \mathrm{~g} \mathrm{pot}^{-1}$ of both $\mathrm{N}$ as $\mathrm{NH}_{4} \mathrm{NO}_{3}$ and $\mathrm{P}_{2} \mathrm{O}_{5}$ as $\mathrm{KH}_{2} \mathrm{PO}_{4}$ in Exp. 1 and Exp. 2, respectively). Potassium was applied to all the pots, including the Cont treatment at the rate of $0.2 \mathrm{~g} \mathrm{pot}^{-1}$ and $0.3 \mathrm{~g} \mathrm{pot}^{-1}$ of $\mathrm{K}_{2} \mathrm{O}$ as $\mathrm{KCl}$ in Exp. 1 and Exp. 2, respectively. Each nutrient was uniformly incorporated into soils one day after being flooded and one day prior to transplanting. Then, two 20-day-old seedlings of a local rice cultivar, X265, grown in free-nutrient sand were transplanted to each pot. The pots were continuously flooded at the depth of 2-5 cm with distilled water throughout the growing periods. The weeds were removed manually, and no specific pest management was required.

\section{Plant analysis}

The plants were harvested at the soil surface, 34 days after transplanting for both Exp. 1 and Exp. 2. Aboveground biomass was determined after oven drying at $70{ }^{\circ} \mathrm{C}$ to a constant weight. Each plant sample was ground into a fine powder using a high-speed vibrating sample mill (Model T1-100, Heiko Co. Ltd., Fukushima, Japan). Then, the plant $\mathrm{P}$ concentration was determined with the molybdate blue method (Murphy and Riley 1962) after dry-ashing at $550{ }^{\circ} \mathrm{C}$ for $2 \mathrm{~h}$ and digestion with $0.5 \mathrm{M} \mathrm{HCl}$. The plant $\mathrm{P}$ uptake (mg P pot ${ }^{-1}$ ) was calculated as the product of aboveground biomass and $\mathrm{P}$ concentration of plants (total P content).

\section{Soil analysis}

The collected soils were air-dried and sieved to $2 \mathrm{~mm}$ for subsequent soil analysis. Soil particle size distribution was determined with the wet-sieving and pipet method (Gee and Bauder 1986). Soil pH was determined in deionized water at a soil-to-solution ratio of 1:2.5. Exchangeable cations $\left(\mathrm{K}^{+}, \mathrm{Na}^{+}, \mathrm{Ca}^{2+}\right.$, and $\left.\mathrm{Mg}^{2+}\right)$ were 

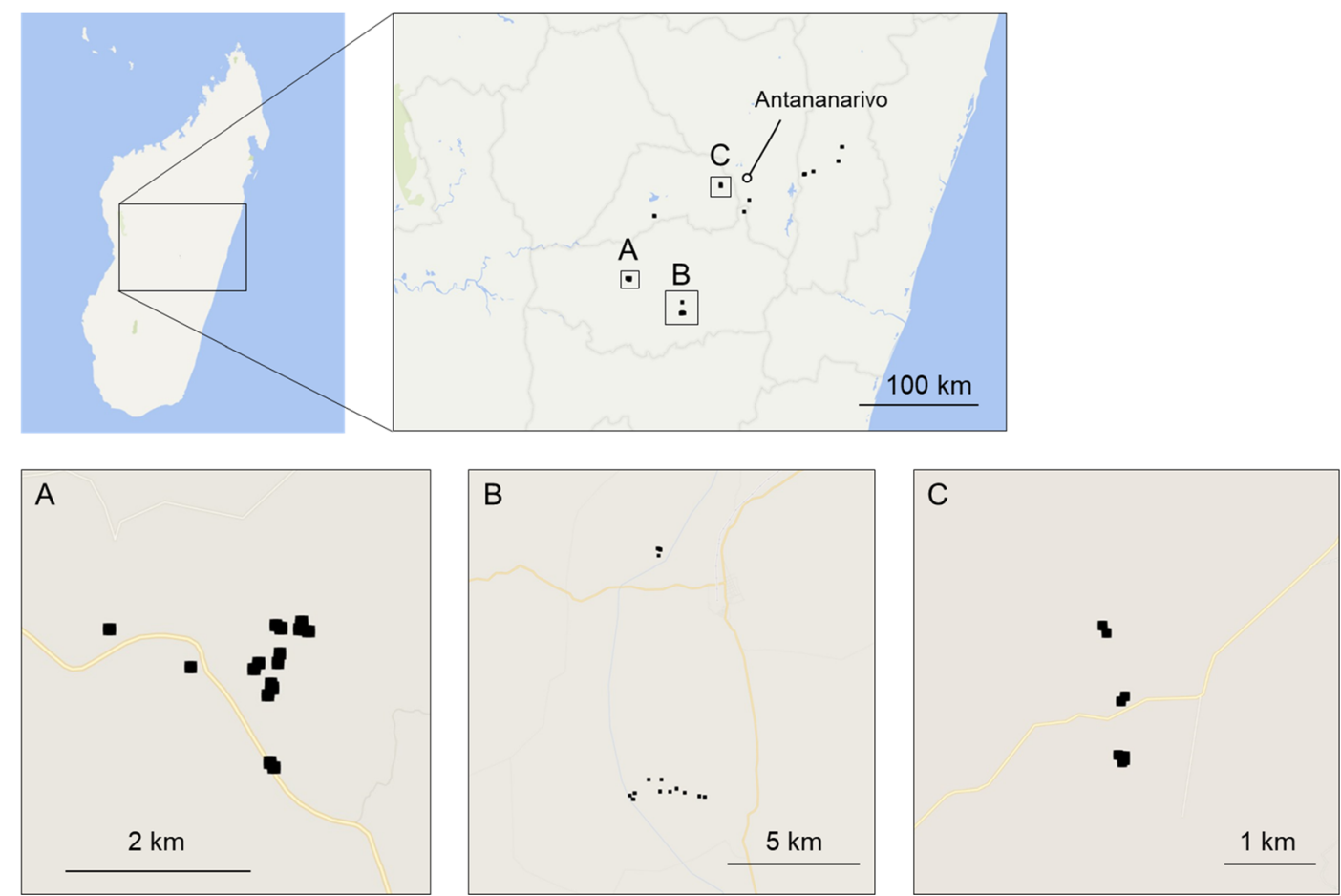

Fig. 1 Map of soil sampling sites. Soils for Exp. 2 were collected from the sites in sub-map A, whereas soils for Exp. 1 were from the other sites

measured following ISRIC protocol (2002), and total exchangeable base was calculated as the sum of those four cations. Total carbon $(\mathrm{C})$ and $\mathrm{N}$ were quantified using the dry combustion method with an NC analyzer (Sumigraph NC-220F, SCAS, Japan). Soil samples were digested in $60 \% \mathrm{HClO}_{4}$ following $\mathrm{Kuo}$ (1996), and total $\mathrm{P}$ was determined with the molybdovanadate method (Kitson and Mellon 1944). Extractable Al, Fe, and P contents were determined with the acid ammonium oxalate method (Alo, Feo, and Oxalate P, respectively) as described by Courchesne and Turmel (2008). The concentrations of $\mathrm{Al}, \mathrm{Fe}$, and $\mathrm{P}$ in the oxalate extraction were measured with an inductively coupled plasma mass spectrometer (ICPE-9000, Shimadzu, Japan).

Soil $\mathrm{P}$ was sequentially fractionated using a modification of the Hedley method (Tiessen and Moir 2007; Sugihara et al. 2012) (Fig. 2). Briefly, $0.5 \mathrm{~g}$ of soil was placed in a $50 \mathrm{~mL}$ centrifuge tube and sequentially extracted with $30 \mathrm{~mL}$ of each of the extractant solutions, which were added in the following order: deionized water (deionized water with two anion-exchange resins in the bicarbonate form; Resin-P), $0.5 \mathrm{M} \mathrm{NaHCO}_{3}(\mathrm{pH} 8.5)\left(\mathrm{NaHCO}_{3}-\mathrm{P}\right), 0.1 \mathrm{M}$ $\mathrm{NaOH}$ (NaOH-P), and $1 \mathrm{M} \mathrm{HCl}$ (HCl-P). Each extraction was performed for $16 \mathrm{~h}$ using a horizontal shaker followed by centrifugation at $2500 \times g$ for
$20 \mathrm{~min}$ at room temperature, and the supernatant was filtered (5C, ADVANTEC) and the filtrate collected to measure the concentration of inorganic $\mathrm{P}$ (Pi) using the molybdate-ascorbic acid method (Murphy and Riley 1962) after $\mathrm{pH}$ adjustment using p-nitrophenol. Each total $\mathrm{P}\left(\mathrm{P}_{\mathrm{i}+\mathrm{o}}\right)$ in $\mathrm{NaHCO}_{3}$ and $\mathrm{NaOH}$ extracts was determined after digestion with ammonium persulfate in an autoclave at $103.5 \mathrm{kPa}$ and $120{ }^{\circ} \mathrm{C}$ for $60 \mathrm{~min}$, and the concentration was determined with the method of Murphy and Riley (1962). The organic P (Po) was calculated as the difference between $\mathrm{P}_{\mathrm{i}+\mathrm{o}}$ and $\mathrm{Pi}$. The difference between total $\mathrm{P}$ in soils and the sum of $\mathrm{Pi}$ and $\mathrm{Po}$ in all the extracted fractions was defined as Residual $\mathrm{P}$.

\section{Statistics}

Statistical analyses were performed using JMP11 software (JMP11.0 Windows, SAS Institute Inc.). First, two-way analysis of variance (ANOVA) was conducted to determine the individual and interaction effects of soils (S) and fertilizer treatments $(\mathrm{T})$ on the aboveground biomass and total $\mathrm{P}$ uptake of rice plants. Second, the obtained aboveground biomass and total $\mathrm{P}$ uptake data for both Exp. 1 and Exp. 2 were standardized into the mean value at 0 with the sample variation at 
Fig. 2 Simple flow chart of the sequential $\mathrm{P}$ extraction according to a modified Hedley method (Tiessen and Moir 2007; Sugihara et al. 2012)

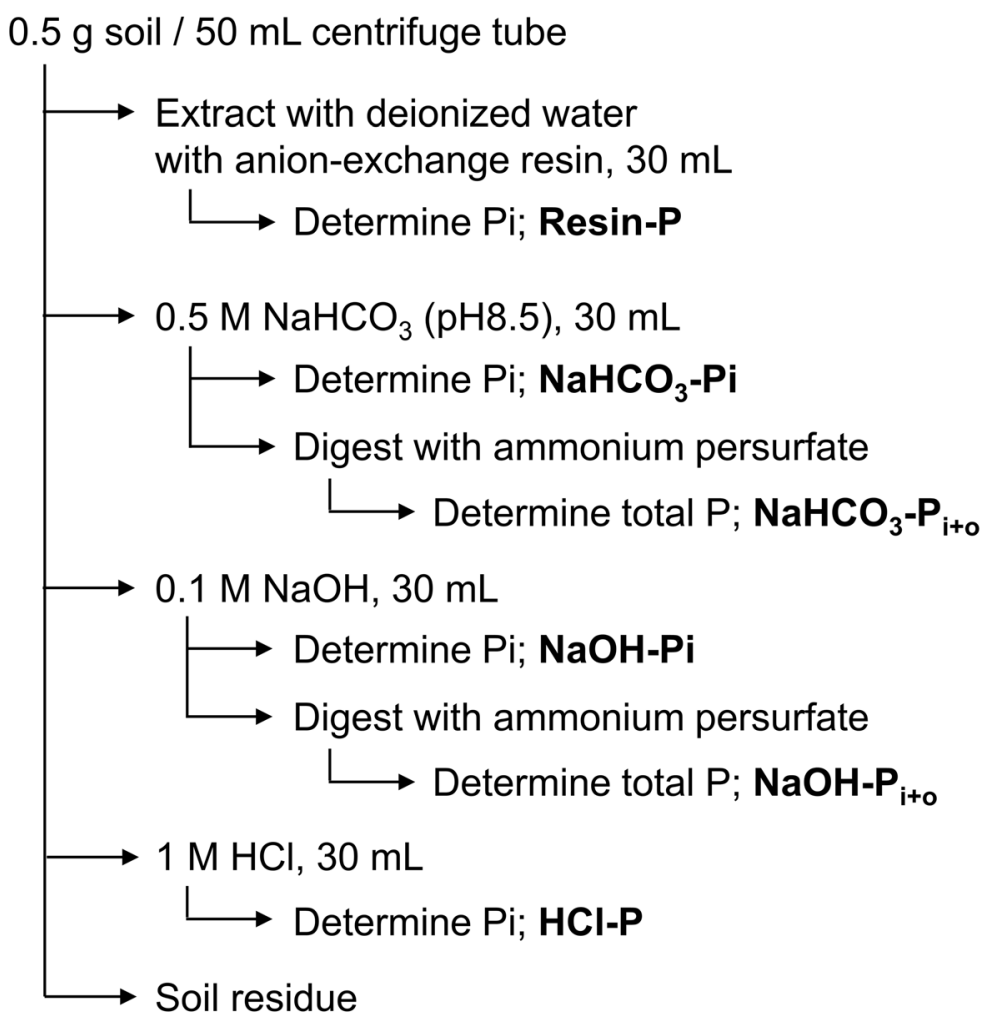

Total $\mathrm{P}$ in soil - sum of extracted $\mathrm{P}=$ Residual $\mathbf{P}$
1 to simultaneously handle the results of two experiments grown under different environmental conditions. Then, a stepwise regression analysis was repeated by applying the $\mathrm{K}$-fold $(\mathrm{K}=5)$ cross validation to develop robust models over two experiments that explained the variations in: 1) total $\mathrm{P}$ uptake in the $+N$ treatment as an index of indigenous soil P-supplying capacity, and 2) differences in $\mathrm{P}$ uptake between the $+N$ and $+N P$ treatments as an index of fertilizer-P recovery efficiency, respectively. The candidate explanatory factors included clay content, total $\mathrm{C}, \mathrm{N}$, and $\mathrm{P}$ contents, soil $\mathrm{pH}$, Alo, $\mathrm{Feo}, \mathrm{Alo}+0.5 \mathrm{Feo}$, Resin-P, $\mathrm{NaHCO}_{3}-\mathrm{Pi}, \mathrm{NaHCO}_{3}-\mathrm{Po}$, $\mathrm{NaOH}-\mathrm{Pi}, \mathrm{NaOH}-\mathrm{Po}$, and HCl-P. In the stepwise process, the 'selection' and 'removal' of factors was controlled with an F-value of $P<0.10$ at each step. The step ended when no remaining candidate factors produced an eligible F-value. Then, a multiple linear regression model was developed using the selected variables. At the end, standardized partial regression coefficients were calculated to assess the effect size of each selected variable. In addition, a $t$-test for the simple regression coefficient was conducted to identify the interrelationship of these soil properties.

\section{Results}

Plant biomass and P uptake

Compared with Exp. 1, Exp. 2 yielded higher values for both aboveground biomass and total P uptake; this was attributable to the higher temperature and rate of nutrient application as well as greater amount of solar radiation during the growing period (Table 1). ANOVA demonstrated highly significant effects of experimental soil, fertilizer treatment, and most importantly of their interactions on aboveground biomass and $\mathrm{P}$ uptake for both Exps. 1 and 2 . Consequently, there were large variations in biomass and $\mathrm{P}$ uptake within each experiment. In a comparison of Fvalues, the magnitude of variations as affected by different soils and treatments was almost equivalent between the two experiments even though the soils for Exp. 2 were collected from adjacent fields in a small area of one village.

The aboveground biomass in the $+N$ treatment ranged from 0.20 to $2.01 \mathrm{~g} \mathrm{pot}^{-1}$ and 1.38 to $6.40 \mathrm{~g} \mathrm{pot}^{-1}$ in Exp. 1 and Exp. 2, respectively (Fig. 3a). The effect of $P$ application, as measured by the difference in biomass between the $+N P$ and $+N$ treatments ( $\triangle$ Biomass), was 
Table 1 Aboveground biomass and P uptake of rice plants as affected by different soils and fertilizer treatments

\begin{tabular}{|c|c|c|c|c|c|c|c|}
\hline & & \multicolumn{3}{|c|}{ Aboveground biomass $\left(\mathrm{g} \mathrm{pot}^{-1}\right.$ ) } & \multicolumn{3}{|c|}{ Plant $\mathrm{P}$ uptake (mg P pot $\left.{ }^{-1}\right)$} \\
\hline & & mean & s.d. & & mean & s.d. & \\
\hline \multirow[t]{3}{*}{ Exp. 1} & Cont & $0.48 \mathrm{c}$ & 0.33 & & $0.63 \mathrm{~b}$ & 0.69 & \\
\hline & $+N$ & $0.75 \mathrm{~b}$ & 0.48 & & $0.81 \mathrm{~b}$ & 0.80 & \\
\hline & $+N P$ & $1.89 \mathrm{a}$ & 0.57 & & $3.29 \mathrm{a}$ & 1.34 & \\
\hline \multirow[t]{3}{*}{ Exp. 2} & Cont & $1.36 \mathrm{c}$ & 0.53 & & $1.89 \mathrm{c}$ & 1.78 & \\
\hline & $+N$ & $3.37 \mathrm{~b}$ & 1.25 & & $3.20 \mathrm{~b}$ & 2.84 & \\
\hline & $+N P$ & $5.60 \mathrm{a}$ & 0.64 & & $10.36 \mathrm{a}$ & 3.59 & \\
\hline \multirow{2}{*}{\multicolumn{2}{|c|}{ ANOVA summary }} & \multicolumn{3}{|c|}{ Aboveground biomass } & \multicolumn{3}{|c|}{ Plant P uptake } \\
\hline & & $\mathrm{df}$ & SS & F-value & $\mathrm{df}$ & SS & F-value \\
\hline \multirow[t]{3}{*}{ Exp. 1} & Soil (S) & 35 & 26.1 & $12.5^{* * *}$ & 16 & 134.2 & $14.6^{* * *}$ \\
\hline & Treatment $(\mathrm{T})$ & 2 & 66.7 & $556.7^{* * *}$ & 2 & 283.4 & $538.6^{* * *}$ \\
\hline & $\mathrm{S} \times \mathrm{T}$ & 70 & 14.1 & $3.4^{* * *}$ & 32 & 69.8 & $3.8^{* * *}$ \\
\hline \multirow[t]{3}{*}{ Exp. 2} & Soil (S) & 16 & 31.9 & $8.7^{* * * *}$ & 16 & 428.1 & $43.5^{* * * *}$ \\
\hline & Treatment $(\mathrm{T})$ & 2 & 296.3 & $645.9^{* * *}$ & 2 & 1275.3 & $1036.2^{* * *}$ \\
\hline & $\mathrm{S} \times \mathrm{T}$ & 32 & 23 & $3.1^{* * *}$ & 32 & 108.3 & $5.5^{* * * *}$ \\
\hline
\end{tabular}

Mean values with different letters indicate significant differences based on Tukey HSD at $P<0.05$

s.d., standard deviation ( $\mathrm{n}=35$ and $\mathrm{n}=16$ for Exp. 1 and Exp. 2, respectively); df, degrees of freedom; SS, sum of squares

$* * * P<0.001$

positive for all soils whereas the increased rate varied greatly among soils, ranging from 0.08 to $2.33 \mathrm{~g} \mathrm{pot}^{-1}$ (Exp. 1) and from 0.40 to $4.72 \mathrm{~g} \mathrm{pot}^{-1}$ (Exp. 2). The same soil-to-soil or field-to-field variations were observed for the $\mathrm{P}$ uptake data in the $+N$ treatment, and $\mathrm{P}$ uptake increased when $\mathrm{P}$ was applied (Fig. 3b). The $\mathrm{P}$ uptake without $\mathrm{P}$ application ( $+N$ treatment) ranged from 0.10 to $2.77 \mathrm{mg} \mathrm{P}_{\text {pot }}{ }^{-1}$ (Exp. 1) and 0.95 to $12.97 \mathrm{mg} \mathrm{P}_{\text {pot }}{ }^{-1}$ (Exp. 2). The increased $P$ uptake when $P$ was applied $(\Delta \mathrm{P}$ uptake; difference between the $+N P$ and $+N$ treatments) ranged from 0.47 to $5.02 \mathrm{mg} \mathrm{P}^{-1}$ pot $^{-1}$ (Exp. 1) and from 2.67 to $10.14 \mathrm{mg} \mathrm{P}$ pot $^{-1}$ (Exp. 2). Interestingly, there were large differences in the response to $\mathrm{P}$ application, i.e., $\Delta$ Biomass and $\Delta \mathrm{P}$ uptake, even among the soils that consistently had low biomass production or $\mathrm{P}$ uptake under $+N$ treatment (P omitted).

Soil characteristics, total $\mathrm{P}$ and fractionated $\mathrm{P}$

The original soils in Exp. 2 had poor nutrient status in terms of total $\mathrm{C}, \mathrm{N}$, and $\mathrm{P}$ compared with the soils in Exp. 1 (Table 2). Because the soils for Exp. 2 were collected from a small area within a single community, the standard deviation values for most soil properties were smaller in Exp. 2 than Exp. 1. The Alo and Alo + $0.5 \mathrm{Feo}$ values were significantly greater for the soils of Exp. 1 than those of Exp. 2, whereas Feo was comparable between the experiments.
Fig. 3 Biomass (a) and $\mathrm{P}$ uptake (b) in the $+N$ treatment and their responses to $\mathrm{P}$ application. $\Delta$ Biomass, the difference in biomass of rice plant between the $+N P$ and $+N$ treatments; $\Delta \mathrm{P}$ uptake, the difference in $\mathrm{P}$ uptake of rice plant between the $+N P$ and $+N$ treatments

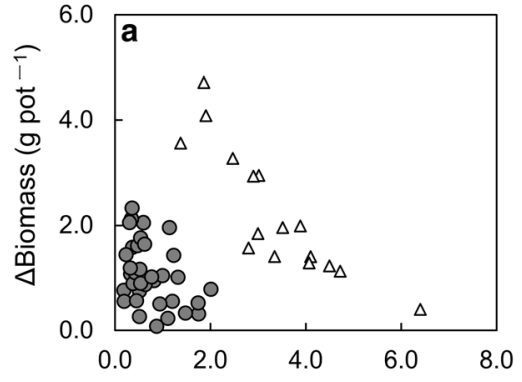

Biomass in $+N$ treatment $\left(\mathrm{g} \mathrm{pot}^{-1}\right)$

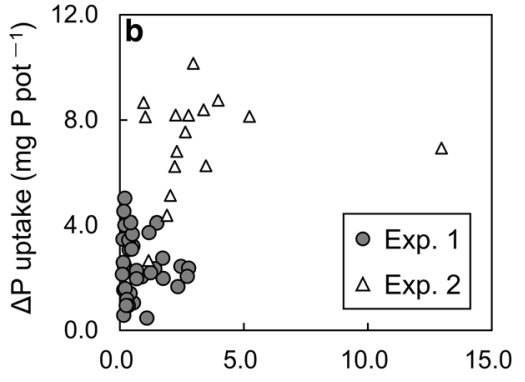

$\mathrm{P}$ uptake in $+N$ treatment $\left(\mathrm{mg} \mathrm{P}^{\mathrm{P}} \mathrm{pot}^{-1}\right)$ 
Table 2 Physicochemical properties of soils for pot-based experiments

\begin{tabular}{|c|c|c|c|c|c|c|c|c|c|}
\hline \multirow[b]{3}{*}{ Total C } & \multirow[b]{3}{*}{$\left(\mathrm{g} \mathrm{C} \mathrm{kg}^{-1}\right)$} & \multicolumn{3}{|c|}{ Exp. 1} & \multicolumn{3}{|c|}{ Exp. 2} & \multicolumn{2}{|c|}{ Total } \\
\hline & & \multicolumn{3}{|c|}{$(\mathrm{n}=35)$} & \multicolumn{3}{|c|}{$(n=16)$} & \multicolumn{2}{|c|}{$(\mathrm{n}=51)$} \\
\hline & & 26 & $\mathrm{a}$ & $(11.0)$ & 14 & $\mathrm{~b}$ & $(5.2)$ & 22 & (11.1) \\
\hline Total N & $\left(\mathrm{g} \mathrm{N} \mathrm{kg}^{-1}\right)$ & 2.0 & $\mathrm{a}$ & $(0.8)$ & 1.2 & $\mathrm{~b}$ & $(0.4)$ & 1.7 & $(0.8)$ \\
\hline Total P & $\left(\mathrm{mg} \mathrm{P} \mathrm{kg}{ }^{-1}\right)$ & 1200 & $\mathrm{a}$ & $(720)$ & 540 & $\mathrm{~b}$ & (190) & 960 & $(670)$ \\
\hline TEB & $\left(\mathrm{cmol}_{\mathrm{c}} \mathrm{kg}^{-1}\right)$ & 3.4 & & $(3.2)$ & 2.8 & & $(2.4)$ & 3.2 & $(3.0)$ \\
\hline $\mathrm{pH}\left(\mathrm{H}_{2} \mathrm{O}\right)$ & & 5.6 & & $(0.4)$ & 5.6 & & $(0.3)$ & 5.6 & $(0.4)$ \\
\hline Clay & $(\%)$ & 32 & & $(8.2)$ & 31 & & $(10.5)$ & 32 & $(9.0)$ \\
\hline Alo & $\left(\mathrm{g} \mathrm{Al} \mathrm{kg}^{-1}\right)$ & 4.3 & $\mathrm{a}$ & $(2.6)$ & 1.4 & $\mathrm{~b}$ & $(0.5)$ & 3.4 & (2.6) \\
\hline Feo & $\left(\mathrm{g} \mathrm{Fe} \mathrm{kg}^{-1}\right)$ & 8.6 & & $(5.0)$ & 5.8 & & $(4.2)$ & 7.7 & $(5.0)$ \\
\hline $\mathrm{Alo}+0.5 \mathrm{Feo}$ & $\left(\mathrm{g} \mathrm{kg}^{-1}\right)$ & 8.6 & $\mathrm{a}$ & $(4.5)$ & 4.3 & $\mathrm{~b}$ & (1.8) & 7.2 & (4.3) \\
\hline
\end{tabular}

The values given in parentheses are standard deviation. Different letters indicate a significant difference between the experiments (Tukey test, $P<0.05)$

TEB, total exchangeable bases (sum of exchangeable $\mathrm{Ca}^{2+}, \mathrm{Mg}^{2+}, \mathrm{Na}^{+}$, and $\mathrm{K}^{+}$); Alo, oxalate-extractable Al; Feo, oxalate-extractable Fe

Total P concentration in all soils ranged from 200 to $3200 \mathrm{mg} \mathrm{P} \mathrm{kg}{ }^{-1}$, with a mean value of $960 \mathrm{mg} \mathrm{P} \mathrm{kg}^{-1}$ (Fig. 4). The amount of $P$ varied substantially among the fractions, with the $\mathrm{NaOH}-\mathrm{Pi}$ value being greatest (260 $\mathrm{mg} \mathrm{P} \mathrm{kg}^{-1}$ on average) followed by $\mathrm{NaOH}-\mathrm{Po}$ (81 $\mathrm{mg} \mathrm{P} \mathrm{kg}^{-1}$ on average). The HCl-P was generally low in most soils (median $8.0 \mathrm{mg} \mathrm{P} \mathrm{kg}^{-1}$ ), but some soils had quite high $\mathrm{HCl}-\mathrm{P}$ values that increased with soil $\mathrm{pH}$. The Resin-P, $\mathrm{NaHCO}_{3}-\mathrm{Pi}$, and $\mathrm{NaHCO}_{3}$-Po values were lower than for the other fractions, namely 12,19 , and $18 \mathrm{mg} \mathrm{P} \mathrm{kg} \mathrm{soil}{ }^{-1}$ on average, respectively. The Oxalate $\mathrm{P}$ in all soils ranged from 49 to $1200 \mathrm{mg} \mathrm{P} \mathrm{kg} \mathrm{soil}{ }^{-1}$ (mean, $330 \mathrm{mg} \mathrm{P} \mathrm{kg} \mathrm{soil}{ }^{-1}$ ). The ratio of the sum of labile $\mathrm{P}$ (Resin-P, $\mathrm{NaHCO}_{3}-\mathrm{Pi}$, and $\mathrm{NaHCO}_{3}-\mathrm{Po}$ ) to total $\mathrm{P}$ was smaller in Exp. 2 (4.9\%) than Exp. 1 (6.1\%). Except for the $\mathrm{NaHCO}_{3}$-Po fraction, all fractions had a significant positive correlation with total $\mathrm{P}$ (Table 3 ).

The Alo values correlated significantly with Resin-P, $\mathrm{NaHCO}_{3}-\mathrm{Pi}$, and $\mathrm{NaOH}-\mathrm{Pi}$, whereas the Feo values correlated only relatively weakly in this respect (Table 3 ). The Alo +0.5 Feo values also correlated significantly with Resin-P, $\mathrm{NaHCO}_{3}-\mathrm{Pi}$, and $\mathrm{NaOH}-\mathrm{Pi}$ (Table 3). The amount of Oxalate P clearly corresponded to the total amount of extractable Pi in all the fractions (TPi) (Fig. 5).

Relationship between responses to fertilizer application and soil properties

Table 4 presents the results of step-wise regression analysis for $\mathrm{P}$ uptake in the $+N$ treatment and for the
Fig. 4 Variation of total phosphorus and fractionated phosphorus among soil samples $(n=51)$. The cross in each box represents the mean, the central vertical bar shows the median, the box represents the interquartile range, the whiskers show the location of the most extreme data points that are still within a factor of 1.5 of the upper or lower quartiles, and the points are values that fall outside the whiskers

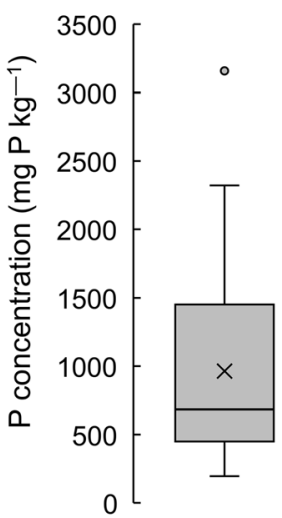

Total P

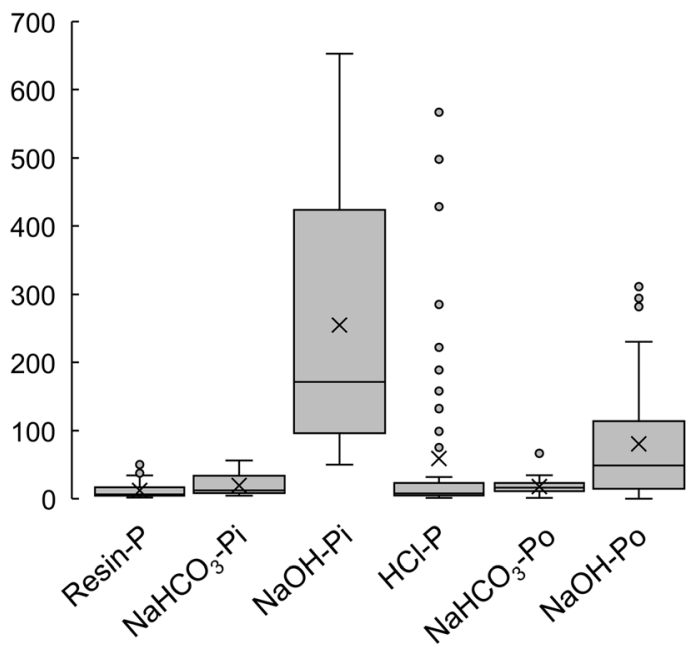


Table 3 Correlation matrix among soil physicochemical properties and fractionated phosphorus

\begin{tabular}{|c|c|c|c|c|c|c|c|c|c|c|c|}
\hline & Total P & $\begin{array}{l}\text { Oxalate } \\
\mathrm{P}\end{array}$ & Resin-P & $\begin{array}{l}\mathrm{NaHCO}_{3-}- \\
\mathrm{Pi}\end{array}$ & $\begin{array}{l}\mathrm{NaOH}- \\
\mathrm{Pi}\end{array}$ & HCl-P & TPi & $\begin{array}{l}\mathrm{NaHCO}_{3}- \\
\mathrm{Po}\end{array}$ & $\begin{array}{l}\mathrm{NaOH}- \\
\text { Po }\end{array}$ & TPo & $\begin{array}{l}\text { Residual } \\
\text { P }\end{array}$ \\
\hline Alo & $\begin{array}{c}0.703 \\
* *\end{array}$ & $0.764 * *$ & $\begin{array}{c}0.619 \\
* *\end{array}$ & $0.719 * *$ & $0.857 * *$ & 0.438 & $\begin{array}{c}0.783 \\
* *\end{array}$ & 0.494 & $0.714 * *$ & $\begin{array}{c}0.724 \\
* *\end{array}$ & 0.476 \\
\hline Feo & $0.552 *$ & $0.700 * *$ & 0.463 & $0.599 * *$ & 0.502 & 0.496 & $0.572 *$ & -0.059 & 0.425 & 0.305 & 0.473 \\
\hline $\mathrm{Alo}+0.5 \mathrm{Feo}$ & $\begin{array}{c}0.733 \\
* *\end{array}$ & $0.854 * *$ & $\begin{array}{r}0.632 \\
* *\end{array}$ & $0.769 * *$ & $0.796 * *$ & $0.544 *$ & $\begin{array}{c}0.792 \\
* *\end{array}$ & 0.259 & $0.655 * *$ & $\begin{array}{c}0.604 \\
* *\end{array}$ & $0.553 *$ \\
\hline $\mathrm{pH}\left(\mathrm{H}_{2} \mathrm{O}\right)$ & 0.374 & 0.456 & 0.342 & 0.357 & 0.201 & $\begin{array}{c}0.618 \\
* *\end{array}$ & 0.418 & -0.447 & -0.093 & -0.090 & 0.368 \\
\hline Clay & -0.145 & -0.256 & -0.246 & -0.188 & -0.071 & -0.413 & -0.237 & 0.284 & 0.121 & 0.139 & -0.106 \\
\hline Total C & 0.367 & 0.351 & 0.227 & 0.385 & $0.603 * *$ & -0.049 & 0.387 & $0.536 *$ & $0.765 * *$ & 0.766 & 0.172 \\
\hline Total P & $\begin{array}{c}1.000 \\
* *\end{array}$ & $0.874 * *$ & $\begin{array}{c}0.782 \\
* *\end{array}$ & $0.894 * *$ & $0.864 * *$ & $\begin{array}{c}0.742 \\
* *\end{array}$ & $\begin{array}{c}0.930 \\
* *\end{array}$ & 0.189 & $0.604 * *$ & $0.575 *$ & $0.939 * *$ \\
\hline Oxalate P & & $1.000 * *$ & $\begin{array}{c}0.890 \\
* *\end{array}$ & $0.915 * *$ & $0.823 * *$ & $\begin{array}{c}0.837 \\
* *\end{array}$ & $\begin{array}{c}0.950 \\
* *\end{array}$ & 0.194 & 0.478 & 0.439 & $0.724 * *$ \\
\hline Resin-P & & & $\begin{array}{c}1.000 \\
* *\end{array}$ & $0.888 * *$ & $0.780 * *$ & $\begin{array}{c}0.772 \\
* *\end{array}$ & $\begin{array}{c}0.898 \\
* *\end{array}$ & 0.251 & 0.331 & 0.309 & $0.628 * *$ \\
\hline $\mathrm{NaHCO}_{3}-\mathrm{Pi}$ & & & & $1.000 * *$ & $0.907 * *$ & $\begin{array}{c}0.710 \\
* *\end{array}$ & $\begin{array}{c}0.953 \\
* *\end{array}$ & 0.276 & $0.567 *$ & 0.503 & $0.743 * *$ \\
\hline $\mathrm{NaOH}-\mathrm{Pi}$ & & & & & $1.000 * *$ & 0.510 & $\begin{array}{c}0.919 \\
* *\end{array}$ & 0.498 & $0.727 * *$ & $\begin{array}{c}0.704 \\
* *\end{array}$ & $0.666 * *$ \\
\hline HCl-P & & & & & & $\begin{array}{c}1.000 \\
* *\end{array}$ & $\begin{array}{c}0.807 \\
* *\end{array}$ & -0.130 & 0.097 & 0.060 & $0.689 * *$ \\
\hline TPi & & & & & & & $\begin{array}{c}1.000 \\
* *\end{array}$ & 0.282 & $0.542 * *$ & 0.505 & $0.770 * *$ \\
\hline $\mathrm{NaHCO}_{3}-\mathrm{Po}$ & & & & & & & & $1.000 * *$ & 0.371 & 0.468 & 0.003 \\
\hline $\mathrm{NaOH}-\mathrm{Po}$ & & & & & & & & & $1.000 * *$ & $\begin{array}{c}0.994 \\
* *\end{array}$ & 0.425 \\
\hline TPo & & & & & & & & & & $\begin{array}{c}1.000 \\
* *\end{array}$ & 0.403 \\
\hline Residual P & & & & & & & & & & & $1.000 * *$ \\
\hline
\end{tabular}

Alo, oxalate-extractable Al; Feo, oxalate-extractable Fe; Oxalate P, oxalate-extractable P; TPi, sum of extracted inorganic P; TPo, sum of extracted organic $\mathrm{P}$; Residual $\mathrm{P}$, difference between total $\mathrm{P}$ in soils and the sum of inorganic and organic $\mathrm{P}$ in all the extracted fractions

$* P<0.01, * * P<0.001$

difference in $\mathrm{P}$ uptake ( $\Delta \mathrm{P}$ uptake) between the $+N$ and $+N P$ treatments using various soil properties. The Resin-P and $\mathrm{NaHCO}_{3}$-Po were selected as the positive explanatory variables for $\mathrm{P}$ uptake in the $+N$ treatment, whereas Alo and total $\mathrm{P}$ were selected as negative explanatory variables. Using these selected parameters, the regression model explained $72 \%$ of the variation in $\mathrm{P}$ uptake of the $+N$ treatment across Exp. 1 and Exp. 2 . The standardized partial regression coefficients indicated that the effect size of selected variables decreased in the order of Resin-P, Alo, $\mathrm{NaHCO}_{3}-\mathrm{Po}$, and total P. Using the same procedure, Alo +0.5 Feo was selected as a strong and negative explanatory variable for $\Delta \mathrm{P}$ uptake. In addition, total $\mathrm{C}$ was selected as a weak and negative explanatory variable $(P=0.051)$. The multiple linear regression analysis of these two variables explained $81 \%$ of the variation in $\Delta \mathrm{P}$ uptake across Exp. 1 and Exp. 2.

\section{Discussion}

Large field-to-field variations in soil P status and response of rice to nutrient inputs

Two sets of pot-based experiments confirmed that the production of irrigated rice- at least in the early growth stage - is limited by P deficiency in most of the soils in the central highland of Madagascar. In addition, there were large field-to-field variations in responses of rice production or $\mathrm{P}$ uptake when $\mathrm{P}$ was omitted $(+N$ treatment) and when $\mathrm{P}$ was applied $(+N P$ treatment $) \mathrm{x}$ 


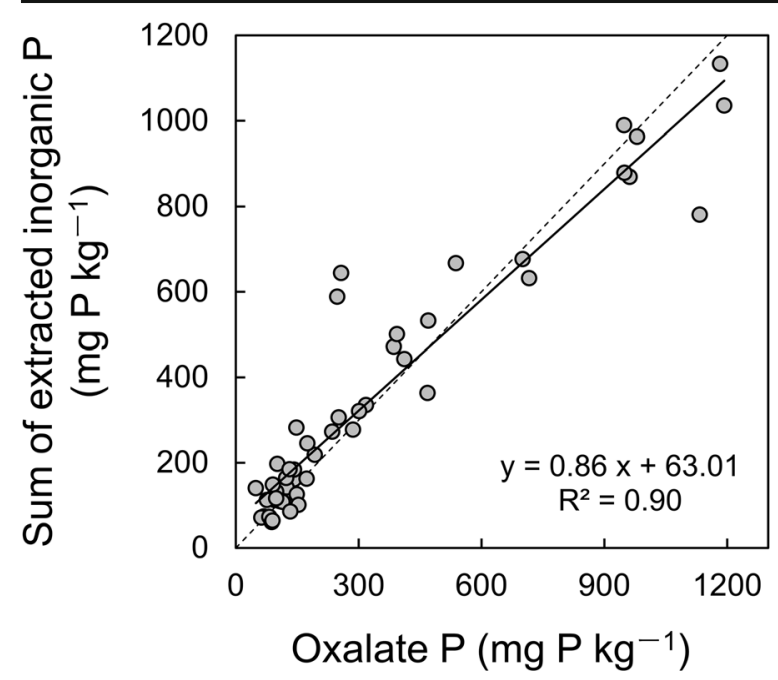

Fig. 5 Relationship between oxalate-extractable $P$ and sum of extracted inorganic P. footer: Solid line shows best fit from regression analysis, and the broken line shows 1:1 ratio

(Table 1, Fig. 3); these large variations in the indigenous soil P-supplying capacity and fertilizer-P recovery efficiencies were confirmed not only for those soils differing in geological backgrounds within a particular region (Exp. 1) but also for soils in adjacent fields in a small area (Exp. 2) (Table 1). The results corroborate recent assertion that better information is needed concerning

Table 4 Multiple regression analysis for plant $\mathrm{P}$ uptake in the $+N$ treatment and difference in $\mathrm{P}$ uptake between the $+N P$ and $+N$ treatments

\begin{tabular}{clll}
\hline & $\begin{array}{l}\text { Selected } \\
\text { variable }\end{array}$ & $\begin{array}{l}\text { Partial } \\
\text { regression } \\
\text { coefficient }\end{array}$ & $\begin{array}{l}\text { Standardized partial } \\
\text { regression } \\
\text { coefficient }\end{array}$ \\
\hline $\begin{array}{c}\text { P uptake in } \\
+N\end{array}$ & Intercept & $-1.170^{\mathrm{ns}}$ & $-0.471^{\mathrm{ns}}$ \\
treatment & Resin-P & $0.034^{* * * *}$ & $0.419^{* * * *}$ \\
& NaHCO $3^{\text {-Po }}$ & $0.021^{* * * *}$ & $0.222^{* * *}$ \\
& Alo & $-0.100^{* * *}$ & $-0.286^{* * *}$ \\
& Total P & $-0.0003^{*}$ & $0.197^{*}$ \\
& Adjusted R square $=0.72$ & \\
$\Delta \mathrm{P}$ uptake & Intercept & $1.010^{\mathrm{ns}}$ & $0.252^{\mathrm{ns}}$ \\
& Alo +0.5 & $-0.056^{* *}$ & $-0.244^{* *}$ \\
& Feo & & \\
& Total C & $-0.158^{\dagger}$ & $-0.177^{\dagger}$ \\
& Adjusted R square $=0.81$ & \\
\hline
\end{tabular}

\footnotetext{
${ }^{a}$ Difference in phosphorus uptake between $+N P$ and $+N$ treatments

$* P<0.05 ; * * P<0.01 ; * * * P<0.001 ; \dagger P=0.051 ; \mathrm{ns}$, not significant
}

Alo, oxalate-extractable Al; Feo, oxalate-extractable Fe differences in the response to applied nutrients within and between fields to effectively increase yields and returns of inputs for smallholder farmers in SSA (e.g. Schut et al. 2018).

Phosphorus is generally considered to have less mobility compared with other plant nutrients because of its strong fixation to the high levels of $\mathrm{Fe}$ and $\mathrm{Al}$ oxides in tropical soils. Therefore, soil P status is relatively consistent within a geological background at the landscape level (Nishigaki et al. 2018). However, our results for soil $\mathrm{P}$ index revealed a substantial variation in total $\mathrm{P}$ and fractionated $\mathrm{P}$ despite the inclusion of samples collected over small distances. Total $\mathrm{P}$ was generally high in the lowland soils compared with the soils collected from adjacent upland fields supposedly due to the replenishment of sediments in runoff water in the lowland fields. Yet, large variations in total $\mathrm{P}$ were observed even within lowland soils in a small area (see Supplementary data sheet). Schmitter et al. (2010) also reported a large spatial variation in soil physicochemical properties in rice paddy terraces in Northwest Vietnam. These results support the importance of site-specific fertilizer management practices based on differences in soil $\mathrm{P}$ status and responses of rice to $\mathrm{P}$ fertilizer. The large variation in soil $\mathrm{P}$ status that we observed in Madagascar could be attributable to land management practices and pervasive soil erosion on the sloping topography.

\section{$\mathrm{P}$ uptake of rice plants in relation to soil P supply capacity}

The result of the regression analysis revealed that $\mathrm{P}$ uptake of rice without $\mathrm{P}$ application was increased by Resin-P and $\mathrm{NaHCO}_{3}-\mathrm{Po}$, indicating that these fractions constitute a readily available $\mathrm{P}$ pool in soils for rice grown under flooded conditions (Table 4). In other words, the indigenous $\mathrm{P}$ supply for lowland rice largely relies on Resin-P, which accounts for merely $1 \%$ of total P in soils (Fig. 4). In addition, our results revealed a quantitative effect of labile organic $\mathrm{P}\left(\mathrm{NaHCO}_{3}-\mathrm{Po}\right)$ on the $\mathrm{P}$ uptake values of rice plants in highly weathered soils. Indeed, previous studies have emphasized the potential role of organic $\mathrm{P}$ pool as a source of available $\mathrm{P}$ in tropical weathered soils (George et al. 2018; Turner 2006).

The total organic $\mathrm{P}$ pool $\left(\mathrm{NaHCO}_{3}-\mathrm{Po}\right.$ and $\mathrm{NaOH}-$ $\mathrm{Po}$ ) in this study was $97 \mathrm{mg} \mathrm{P} \mathrm{kg}^{-1}$, representing $10 \%$ of total $\mathrm{P}$. This is comparable with results of a previous report on soil organic $\mathrm{P}$ in rice fields in Madagascar, i.e., the Po pool ranged from $6.7 \%$ to $29 \%$ (Turner 2006). 
Randriamanantsoa et al. (2015) reported that gross organic $\mathrm{P}$ mineralization rates were $0.8 \pm 0.5 \mathrm{mg} \mathrm{P}$ $\mathrm{kg}^{-1} \mathrm{day}^{-1}$ and $1.7 \pm 0.2 \mathrm{mg} \mathrm{P} \mathrm{kg}^{-1} \mathrm{day}^{-1}$ in nonamended and residue-amended Ferralsols, respectively. Our results and those of these previous studies also support the potential role for soil organic $\mathrm{P}$ in rice nutrition at the initial growth stage in tropical soils that typically have low available inorganic P. On the other hand, Alo in soils had a negative effect on P uptake of rice. This is likely attributable to the high sorption capacity of active Al in soils (Agbenin 2003; Nwoke et al. 2003). We therefore conclude that the P-supplying capacity of strongly weathered rice-fields is mainly controlled by the size of the labile inorganic and organic $\mathrm{P}$ pools and the sorption capacity of the soil matrix. However, the potential contribution of less-labile P fractions through the root-induced chemical reactions in rhizosphere soils (Hinsinger 2001) should not be completely excluded when we consider relatively low $\mathrm{P}$ mobility in highly weathered soils and the mass balance between $\mathrm{P}$ uptakes of rice plants and labile $\mathrm{P}$ pools in rhizosphere soils.

Effect of oxalate-extractable Al, Fe, and $\mathrm{P}$ on fertilizer-P recovery efficiency and $\mathrm{P}$ cycling

The result of the regression analysis revealed that the difference in $\mathrm{P}$ uptake between the $+N P$ and $+N$ treatments was strongly controlled by the Alo +0.5 Feo (Table 4). This underscores the importance of $\mathrm{Al}$ and $\mathrm{Fe}$ (hydr)oxides in regulating fertilizer-P recovery efficiency for lowland rice production in highly weathered soils. This suggests that the applied P was mainly sorbed to the active $\mathrm{Al}$ and $\mathrm{Fe}$, and hence $\mathrm{P}$ availability for plants decreased. Sugihara et al. (2012) reported that $P$ in fertilizer was predominantly fixed by $\mathrm{Al}$ and $\mathrm{Fe}$ oxides in a clay-rich maize cropland in Tanzania. Nwoke et al. (2003) also suggested that oxalate-extractable $\mathrm{Al}$ and $\mathrm{Fe}$ can regulate the standard $\mathrm{P}$ requirement and $\mathrm{P}$ availability in soils of the West African savanna.

We found that the Alo +0.5 Feo correlated positively with each inorganic $\mathrm{P}$ fraction, and most highly with $\mathrm{NaHCO}_{3}-\mathrm{Pi}$ and $\mathrm{NaOH}-\mathrm{Pi}$, suggesting that $\mathrm{P}$ in these labile and less-labile fractions is mainly associated with the active $\mathrm{Al}$ and $\mathrm{Fe}$. Despite the large proportion of $\mathrm{NaOH}-\mathrm{Pi}$ in total $\mathrm{P}$ (Fig. 4), NaOH-Pi did not contribute to the $\mathrm{P}$ uptake of rice in $+N$ treatment owing to the low availability of $\mathrm{P}$ strongly fixed by the active $\mathrm{Al}$ and $\mathrm{Fe}$. Considering the higher regression coefficients for Alo than Feo with $\mathrm{NaHCO}_{3}-\mathrm{Pi}$ and $\mathrm{NaOH}-\mathrm{Pi}$, Alo is likely to be the main controlling factor for those fractions. Nwoke et al. (2003) suggested that Al plays a greater role than $\mathrm{Fe}$ in removing $\mathrm{P}$ from soil solution of the surface layer because the $\mathrm{pH}$ values of soils are in the range in which $\mathrm{P}$ is more likely to react with $\mathrm{Al}$ than with Fe.

It has been reported that the application of organic matter, such as animal manure, can decrease P sorption and increase $\mathrm{P}$ availability in highly weathered soils (Azeez and Averbeke 2011; Guppy et al. 2005), owing to competition between organic matter molecules and $\mathrm{P}$ for the available sorbing sites on soil particles (Chassé and Ohno 2016). Hence, farmyard manure application, which is widely used for agricultural lands in the central highlands of Madagascar, is indeed and effective management option for improving the phytoavailability of applied phosphate in weathered soils. Andriamananjara et al. (2018) reported that farmyard manure application to weathered upland soils of Madagascar increases P fertilizer recovery efficiency for upland rice.

Our results reveal that the amount of Oxalate $\mathrm{P}$ clearly corresponded to sum of extracted inorganic $\mathrm{P}$ (Fig. 5). This fact leads us to surmise that Oxalate $P$ represents all the labile and less-labile inorganic $\mathrm{P}$ pools in soils. Most of the $\mathrm{P}$ sorbed by active Fe and $\mathrm{Al}$ compounds is slowly released back to the soil solution, providing service flows for 5 to 10 years (Sanchez et al. 1997). Agbenin and Goladi (1998) indicated that Resin-P is attributable to the less-labile $\mathrm{P}$ sources, namely $\mathrm{NaOH}-\mathrm{Pi}$ and $\mathrm{HCl}-\mathrm{P}$, which act as sinks for fertilizer-P. These results suggest that Oxalate $\mathrm{P}$ can be an index for the evaluation of both labile and less-labile $\mathrm{P}$ pools, namely the moderately active $\mathrm{P}$ pool, which may be involved in the subsequent slow $\mathrm{P}$ cycling in rice croplands (Lookman et al. 1995). This could account for why many previous studies, which were mostly conducted using soils with an abundant labile P pool, have shown that Oxalate P is poorly effective at predicting $\mathrm{P}$ uptake by crops (Eichler-Löbermann et al. 2007; Nawara et al. 2017). Interestingly, however, we found a significant correlation between $\mathrm{P}$ uptake and Oxalate $\mathrm{P}$ in both Exp. 1 ( $r=0.75, P<0.001$ in the Cont treatment) and Exp. 2 ( $r=0.72, P<0.01$ in the Cont treatment). This is likely attributable to the fact that less-labile $\mathrm{P}$ in tropical weathered soils is more abundant than in temperate soils and, therefore, the overall effect of less-labile P is greater in tropical weathered soils. 


\section{Conclusion}

Our experiments successfully extracted the most relevant soil components to determine the indigenous soil Psupplying capacity and fertilizer-P recovery efficiencies for rice production. Phosphorus uptake of rice in the early growth stage is tightly controlled by labile inorganic and organic $\mathrm{P}$ pools and active $\mathrm{Al}$ and $\mathrm{Fe}$ in $\mathrm{P}$ deficient weathered soils. In addition, a high degree of variability in rice $\mathrm{P}$ uptake in response to fertilizer treatment and soil characteristics is observed even within a small area. These results provide fundamental information for developing more effective nutrient management practices and improving financial returns for individual fields. Further studies are required to determine whether the results from our pot-based experiments are applicable to the responses of rice in the field. To achieve practical field-specific fertilizer management, further studies are also needed to reveal how to increase available $\mathrm{P}$ - in both inorganic and organic forms - and to reduce the activity of $\mathrm{Al}$ and $\mathrm{Fe}$ oxides in highly weathered soils.

Acknowledgments The authors are grateful to Dr. Patrick E. Hayes for his valuable comments on this manuscript. We also thank Ms. Mayumi Yonemura for assisting with the laboratory analysis. This research was financially supported by the Science and Technology Research Partnership for Sustainable Development (SATREPS), Japan Science and Technology Agency (JST)/ Japan International Cooperation Agency (JICA).

Open Access This article is distributed under the terms of the Creative Commons Attribution 4.0 International License (http:// creativecommons.org/licenses/by/4.0/), which permits unrestricted use, distribution, and reproduction in any medium, provided you give appropriate credit to the original author(s) and the source, provide a link to the Creative Commons license, and indicate if changes were made.

\section{References}

Agbenin JO (2003) Extractable iron and aluminum effects on phosphate sorption in a savanna Alfisol. Soil Sci Soc Am J 67:589-595

Agbenin JO, Goladi JT (1998) Dynamics of phosphorus fractions in a savanna Alfisol under continuous cultivation. Soil Use Manag 14:59-64

Andriamananjara A, Rakotoson T, Razanakoto OR, Razafimanantsoa M-P, Rabeharisoa L, Smolders E (2018) Farmyard manure application in weathered upland soils of
Madagascar sharply increase phosphate fertilizer use efficiency for upland rice. Field Crop Res 222:94-100

Azeez JO, Averbeke WV (2011) Effect of manure types and period of incubation on phosphorus-sorption indices of a weathered tropical soil. Comm Soil Sci Plant Anal 42:2200-2218

Balemi T, Negisho K (2012) Management of soil phosphorus and plant adaptation mechanisms to phosphorus stress for sustainable crop production: a review. J Soil Sci Plant Nutr 12: 547-561

Beck MA, Sanchez PA (1994) Soil phosphorus fraction dynamics during 18 years of cultivation on a Typic Paleudult. Soil Sci Soc Am J 34:1424-1431

Chassé AW, Ohno T (2016) Higher molecular mass organic matter molecules compete with orthophosphate for adsorption to iron (oxy)hydroxide. Env Sci Tech 50:7461-7469

Courchesne F, Turmel MC (2008) Extractable Al, Fe, Mn, and Si. In: Carter MR, Gregorich EG (eds) In Soil sampling and methods of analysis, 2nd edn. Canadian Society of Soil Science, CRC Press, Boca Raton

Dogbe W, Sogbedji JM, Buah SSJ (2015) Site-specific nutrient management for lowland rice in the northern Savannah zones of Ghana. Curr Agr Res 3:109-117

Eichler-Löbermann B, Köhne S, Köppen D (2007) Effect of organic, inorganic, and combined organic and inorganic $\mathrm{P}$ fertilization on plant $\mathrm{P}$ uptake and soil P pools. J Plant Nutr Soil Sci 170:623-628

Fageria NK, Baligar VC (1997) Response of common bean, upland rice, corn, wheat, and soybean to soil fertility of an Oxisol. J Plant Nutr 20:1279-1289

Fageria NK, Carvalho GD, Santos AB, Ferreira EPB, Knupp AM (2011) Chemistry of lowland rice soils and nutrient availability. Comm Soil Sci Plant Anal 42:1913-1933

Gee GW, Bauder JW (1986) Particle-size analysis. In: Klute A (ed) Method of soil analysis part 1 . Physical and mineralogical methods. Agronomy monograph no. 9, second ed. American Society of Agronomy and Soil Science of America, Wisconsin, pp 383-411

George TS, Giles CD, Menezes-Blackburn D et al (2018) Organic phosphorus in the terrestrial environment: a perspective on the state of the art and future priorities. Plant Soil 427:191208

Guo F, Yost RS, Hue NV, Evensen CI, Silva JA (2000) Changes in phosphorus fractions in soils under intensive plant growth. Soil Sci Soc Am J 64:1681-1689

Guppy CN, Menzies NW, Moody PW, Blamey FPC (2005) Competitive sorption reactions between phosphorus and organic matter in soil: a review. Soil Res 43:189-202

Haynes RJ, Mokolobate MS (2001) Amelioration of Al toxicity and $\mathrm{P}$ deficiency in acid soils by additions of organic residues: a critical review of the phenomenon and the mechanisms involved. Nutr Cycl Agroecosyst 59:47-63

Hedley MJ, Stewart JWB, Chauhan BS (1982) Changes in inorganic and organic soil phosphorus fractions induced by cultivation practices and by laboratory incubations. Soil Sci Soc Am J 46:970-976

Hinsinger P (2001) Bioavailability of soil inorganic P in the rhizosphere as affected by root-induced chemical changes: a review. Plant Soil 237:173-195

ISRIC (2002) Cation exchange capacity (CEC) and exchangeable bases (ammonium acetate method). In: van Reeuwijk LP (ed) 
Procedures for soil analysis. International Soil Reference and Information Centre, Wageningen, p 9-1-9-14

Kihara J, Nziguheba G, Zingore S, Coulibaly A, Esilaba A, Kabambe V, Njoroge S, Palm C, Huising J (2016) Understanding variability in crop response to fertilizer and amendments in sub-Saharan Africa. Agric Ecosyst Environ 229:1-12

Kitson RE, Mellon MG (1944) Colorimetric determination of phosphorus as molybdivanadophosporic acid. Ind Eng Chem Anal Ed 16:379-383

Koné B, Amadji GL, Aliou S, Diatta S, Akakpo C (2011) Nutrient constraint and yield potential of rice on upland soil in the south of the Dahoumey gap of West Africa. Arch Agron Soil Sci 57:763-774

Koné B, Fofana M, Sorho F, Diatta S, Ogunbayo A, Moussa S (2013) Nutrient constraint of rainfed rice production in foot slope soil of Guinea Forest in Côte d'Ivoire. Arch Agron Soil Sci 60:735-746

Kuo S (1996) Phosphorus. In: Sparks DL (ed) Methods of Soil Analysis. Agronomy 9. ASA-SSA, Madison, Wisconsin, USA, pp 869-919

Lookman R, Freese D, Merckx R, Vlassak K, van Riemsdijk WH (1995) Long-term kinetics of phosphate release from soil. Environ Sci Technol 29:1569-1575

Menezes-Blackburn D, Giles C, Darch T, George TS, Blackwell M, Stutter M, Shand C, Lumsdon d CP, Wendler R, Brown L, Almeida DS, Wearing C, Zhang H, Haygarth PM (2017) Opportunities for mobilizing recalcitrant phosphorus from agricultural soils: a review. Plant Soil 427:5-16

Murphy J, Riley JP (1962) A modified single solution method for the determination of phosphate in natural waters. Anal Chem Acta 27:31-36

Nawara S, Van Dael T, Merckx R, Amery F, Elsen A, Odeurs W, Vandendriessche H, Mcgrath S, Roisin C, Jouany C, Pellerin S, Denoroy P, Eichler-Löbermann B, Börjesson G, Goos P, Akkermans W, Smolders E (2017) A comparison of soil tests for available phosphorus in long-term field experiments in Europe. Eur J Soil Sci 68:873-885

Nishigaki T, Sugihara S, Kobayashi K, Hashimoto Y, Kilasara M, Tanaka H, Watanabe T, Funakawa S (2018) Fractionation of phosphorus in soils with different geological and soil physicochemical properties in southern Tanzania. Soil Sci Plant Nutr 64:291-299

Nwoke OC, Vanlauwe B, Diels J, Sanginga N, Osonubi O, Merckx R (2003) Assessment of labile phosphorus fractions and adsorption characteristics in relation to soil properties of west African savanna soils. Agric Ecosyst Environ 100:285294

Nziguheba G, Zingore S, Kihara J, Merckx R, Njoroge S, Otinga A, Vandamme E, Vanlauwe B (2016) Phosphorus in smallholder farming systems of sub-Saharan Africa: implications for agricultural intensification. Nutr Cycl Agroecosyst 104: $321-340$

Randriamanantsoa L, Frossard E, Oberson A, Bünemann EK (2015) Gross organic phosphorus mineralization rates can be assessed in a Ferralsol using an isotopic dilution method. Geoderma 257-258:86-93

Saito K, Diack S, Dieng I, N'Diaye MK (2015a) On-farm testing of a nutrient management decision-support tool for rice in the Senegal River valley. Comput Electron Agr 116:36-44
Saito K, Dieng I, Toure AA, Somado EA, Wopereis MSC (2015b) Rice yield growth analysis for 24 African countries over 1960-2012. Glob Food Secur 5:62-69

Sanchez PA, Shepherd KD, Soule MJ, Place FM, Buresh RJ, Izac AN, Mokwunye AU, Kwesiga FR, Ndiritu CG, Woomer PL (1997) Soil fertility replenishment in Africa: an investment in natural resource capital. In: Buresh RJ, Sanchez PA, Calhoun F (eds) Replenishing soil fertility in Africa. SSSA Special Publication Number, vol 51, pp 1-46

Schmitter P, Dercon G, Hilger T, Thi Le Ha T, Huu Thanh N, Lam N, Duc Vien T, Cadisch G (2010) Sediment induced soil spatial variation in paddy fields of Northwest Vietnam. Geoderma 155:298-307

Schut AGT, Traore PCS, Blaes X, de By RA (2018) Assessing yield and fertilizer response in heterogeneous smallholder fields with UAVs and satellites. Field Crop Res 221:98-107

Shehu BM, Merckx R, Jibrin JM, Kamara AY, Rurinda J (2018) Quantifying variability in maize yield response to nutrient applications in the northern Nigerian savanna. Agronomy 8: 18

Sugihara S, Funakawa S, Nishigaki T, Kilasara M, Kosaki T (2012) Dynamics of fractionated $\mathrm{P}$ and $\mathrm{P}$ budget in soil under different land management in two Tanzanian croplands with contrasting soil textures. Agric Ecosyst Environ 162:101107

Tiessen H, Moir JO (2007) Characterization of available phosphorus by sequential extraction. In: Carter MR, Gregorich EG (eds) Soil sampling and methods of analysis, second edition, Canadian Society of Soil Science. Lewis. Publishers, Boca Raton, pp 293-306

Tiessen H, Salcedo IH, Sampaio EVSB (1992) Nutrient and soil organic matter dynamics under shifting cultivation in semiarid northeastern Brazil. Agric Ecosyst Environ 38:139-151

Turner BL (2006) Organic phosphorus in Madagascan rice soils. Geoderma 136:279-288

Van Oort PAJ, Saito K, Tanaka A, Amovin-Assagba E, Van Bussel LGJ, Van Wart J, De Groot H, Van Ittersum MK, Cassman KG, Wopereis MCS (2015) Assessment of rice selfsufficiency in 2025 in eight African countries. Glob Food Secur 5:39-49

Van Vuuren DP, Bouwman AF, Beusen AHW (2010) Phosphorus demand for the 1970-2100 period: a scenario analysis of resource depletion. Glob Environ Change 20:428-439

Yan X, Wang D, Zhang H, Zhang G, Wei Z (2013) Organic amendments affect phosphorus sorption characteristics in a paddy soil. Agric Ecosyst Environ 175:47-53

Yanai J, Lee CK, Kaho T, Iida M, Matsui T, Umeda M, Kosaki T (2012) Geostatistical analysis of soil chemical properties and rice yield in a paddy field and application to the analysis of yield-determining factors. Soil Sci Plant Nutr 47:291-301

Zhang Q, Wang GH, Feng YK, Sun QZ, Witt C, Dobermann A (2006) Changes in soil phosphorus fractions in a calcareous paddy soil under intensive rice cropping. Plant Soil 288:141154

Zingore S, Tittonell P, Corbeels M, van Wijk MT, Giller KE (2011) Managing soil fertility diversity to enhance resource use efficiencies in smallholder farming systems: a case from Murewa District, Zimbabwe. Nutr Cycl Agroecosyst 90: 87-103 